\title{
Commentaries on Translational Impact: Psychologically Wise Policies \\ Targeting Inequality Require Acknowledgement of Scarcity \\ Mindsets, Mobility Beliefs, and Class Privilege Justifications
}

Alexander S. Browman

Boston College

CAmerican Psychological Association, 2019. This paper is not the copy of record and may not exactly replicate the authoritative document published in the APA journal.

The final article is available, upon publication, at: http://dx.doi.org/10.1037/tps0000202 


\begin{abstract}
High and rising economic inequality has prompted concerns about the consequences for opportunity and mobility for those from less advantaged backgrounds. I propose that an appreciation of three psychological phenomena-(1) how scarcity affects decision-making, and how (2) the belief in upward mobility and (3) the justification of class privilege help legitimize and maintain economic inequality — is critical to the development of psychologically wise policies targeting inequality_policies that acknowledge and address specific psychological processes that are known to help sustain and perpetuate inequality. I highlight the implications of expanding consumer choice for individuals facing scarcity, and the effects of people's tendency to overestimate mobility rates on support for policies designed to reduce inequality.
\end{abstract}




\section{Commentaries on Translational Impact: Psychologically Wise Policies}

\section{Targeting Inequality Require Acknowledgement of Scarcity}

\section{Mindsets, Mobility Beliefs, and Class Privilege Justifications}

High and rising economic inequality has prompted concerns about the consequences for opportunity and mobility for those from less advantaged backgrounds. Fittingly, Ryan, Singh, Hentschke, and Bullock (2018) provide a timely review of research on and the implications of three relevant psychological phenomena: (1) how the experience of scarcity affects decisionmaking, and how (2) the belief in upward mobility and (3) the justification of class privilege help legitimize and maintain economic inequality. I contend that these phenomena are critical to the development of psychologically wise policies targeting inequality—policies that acknowledge and address specific psychological processes that are known to help sustain and perpetuate inequality.

Acknowledging the role of scarcity in decision-making is critical to the development of psychologically wise policies regarding the expansion of choice. In the U.S., for example, recent policy initiatives have focused on increasing "consumer" choice in important domains like health insurance (e.g., Trump, 2017) and education (e.g., DeVos, 2017). However, making informed choices on complex, long-term issues like these requires careful comparison of the available options. This requires cognitive capacity; without it, people often base their decisions on easily digestible information (e.g., a healthcare plan being heavily advertised as low-cost) than on more important but complex information (e.g., lengthy documents detailing that the plan provides little coverage), and thus make sub-optimal decisions that are harmful in the long run (Robertson \& Yokum, 2014; Shafir, 2017). A consideration of the effects of scarcity on cognitive capacity and associated decision-making is therefore critical when evaluating how proposed policies will affect chronically disadvantaged members of society. 
Furthermore, policy decisions regarding social safety net programs must be wise to people's tendencies to overestimate upward mobility and legitimize class privilege. As Ryan and colleagues (2018) discuss, Americans frequently overestimate the extent to which upward mobility is attainable through hard work in their country (Davidai \& Gilovich, 2015; Kraus \& Tan, 2015), which promotes the mindset that both wealth and poverty are deserved and thus policies like taxation and redistribution are unfair (Alesina, Stantcheva, \& Teso, 2018; Day \& Fiske, 2017; Shariff, Wiwad, \& Aknin, 2016). This is critical, as many policy initiatives in recent decades have weaponized these misperceptions to justify cutting or restricting access to safety net programs (Sethi, 2010). For example, speaking about the need for such cuts, a chairman of the Senate Committee on Finance recently stated, "I have rough time wanting to spend... trillions of dollars to help people who won't help themselves, won't lift a finger... [to take advantage of] the opportunities that this great country grants them" (C-SPAN, 2017). The belief that "opportunities" to success and mobility are available to anyone willing to "help themselves" thus enables people to justify class privilege and oppose policies that challenge it, which ultimately helps to maintain inequality. While there are positives to believing that mobility is possible and can be fairly earned (Browman, Destin, Carswell, \& Svoboda, 2017; Laurin, Fitzsimons, \& Kay, 2011; for review, see Browman, Destin, Kearney, \& Levine, 2019), efforts to increase support for inequality-reducing policies should begin by educating people about both the current improbability of experiencing mobility (e.g., Chetty et al., 2017) and the notable contribution of external factors to both wealth and poverty (e.g., Adermon, Lindahl, \& Waldenström, 2018).

Ryan and colleagues (2018) contend that " "minding the gap' requires translating psychological research into action" (p. 195). The present examples support this notion that an appreciation of psychological phenomena — including scarcity mindsets, mobility beliefs, and 
class privilege justifications - is indeed essential to the creation of policies that are wise to the otherwise hidden factors that help maintain inequality. 


\section{References}

Adermon, A., Lindahl, M., \& Waldenström, D. (2018). Intergenerational Wealth Mobility and the Role of Inheritance: Evidence from Multiple Generations. Economic Journal. https://doi.org/10.1111/ecoj.12535

Alesina, A., Stantcheva, S., \& Teso, E. (2018). Intergenerational Mobility and Preferences for Redistribution. American Economic Review, 108(2), 521-554. https://doi.org/10.1257/aer.20162015

Browman, A. S., Destin, M., Carswell, K. L., \& Svoboda, R. C. (2017). Perceptions of Socioeconomic Mobility Influence Academic Persistence among Low Socioeconomic Status Students. Journal of Experimental Social Psychology, 72(9), 45-52. https://doi.org/10.1016/j.jesp.2017.03.006

Browman, A. S., Destin, M., Kearney, M. S., \& Levine, P. B. (2019). How economic inequality shapes mobility expectations and behaviour in disadvantaged youth. Nature Human Behaviour, 3(3), 214-220. https://doi.org/10.1038/s41562-018-0523-0

C-SPAN. (2017). Senate Session: Members considered the Senate Republican tax reform bill. United States: C-SPAN.

Chetty, R., Grusky, D., Hell, M., Hendren, N., Manduca, R., \& Narang, J. (2017). The fading American dream: Trends in absolute income mobility since 1940. Science, 356(6336), 398406. https://doi.org/10.1126/science.aal4617

Davidai, S., \& Gilovich, T. (2015). Building a More Mobile America-One Income Quintile at a Time. Perspectives on Psychological Science, 10(1), 60-71. https://doi.org/10.1177/1745691614562005

Day, M. V., \& Fiske, S. T. (2017). Movin’ on Up? How Perceptions of Social Mobility Affect Our Willingness to Defend the System. Social Psychological and Personality Science, 8(3), 
267-274. https://doi.org/10.1177/1948550616678454

DeVos, B. (2017). Prepared Remarks by Secretary DeVos to JFK Jr. Forum at Harvard Kennedy School. Retrieved February 27, 2019, from https:/www.ed.gov/news/speeches/preparedremarks-secretary-devos-jfk-jr-forum-harvard-kennedy-school

Kraus, M. W., \& Tan, J. J. X. (2015). Americans overestimate social class mobility. Journal of Experimental Social Psychology, 58, 101-111. https://doi.org/10.1016/j.jesp.2015.01.005

Laurin, K., Fitzsimons, G. M., \& Kay, A. C. (2011). Social disadvantage and the self-regulatory function of justice beliefs. Journal of Personality and Social Psychology, 100(1), 149-171. https://doi.org/10.1037/a0021343

Robertson, C. T., \& Yokum, D. V. (2014). The Burden of Deciding For Yourself: The Disutility Caused by Out-of-Pocket Healthcare Spending. Indiana Health Law Review, 11(2), 609634.

Ryan, D. A., Singh, M. R., Hentschke, E. A., \& Bullock, H. E. (2018). “Minding the gap": Social psychological insights for strengthening interclass relations and advancing economic justice. Translational Issues in Psychological Science, 4(2), 187-197. https://doi.org/10.1037/tps0000158

Sethi, J. (2010). Lessons for Social Scientists and Politicians: An Analysis of Welfare Reform. Georgetown Journal on Poverty Law \& Policy, 17(1), 5-32.

Shafir, E. (2017). Decisions in poverty contexts. Current Opinion in Psychology, 18(Dec), 131136. https://doi.org/10.1016/j.copsyc.2017.08.026

Shariff, A. F., Wiwad, D., \& Aknin, L. B. (2016). Income Mobility Breeds Tolerance for Income Inequality. Perspectives on Psychological Science, 11(3), 373-380. https://doi.org/10.1177/1745691616635596

Trump, D. J. Presidential Executive Order Promoting Healthcare Choice and Competition Across 
the United States (2017). United States. Retrieved from

https://www.whitehouse.gov/presidential-actions/presidential-executive-order-promoting-

healthcare-choice-competition-across-united-states/ 